\title{
PENERAPAN MODEL PEMBELAJARAN KOOPERATIF TIPE JIGSAW UNTUK MENINGKATKAN AKTIVITAS DAN HASIL BELAJAR MATA KULIAH TEORI DAN PRAKTEK RENANG II
}

\author{
I Gede Suwiwa \\ Jurusan Pendidikan Jasmani Kesehatan dan Rekreasi,Fakultas Olahraga dan \\ Kesehatan, Universitas Pendidikan Ganesha \\ Singaraja, Indonesia \\ E-mail: gedesuwiwakutuh@yahoo.co.id
}

\begin{abstract}
Abstrak
Penelitian ini bertujuan untuk meningkatkan aktivitas dan hasil belajar mata kuliah teori dan praktek renang II. Penelitian merupakan penelitian tindakan kelas yang dilaksanakan selama 2 siklus dengan subjek penelitiannya mahasiswa semester II Jurusan Pendidikan Jasmani, kesehatan dan Rekreasi. Data penelitian ini diperoleh dari hasil pengamatan aktivitas belajar dan hasil belajar renang gaya dada dan kupu-kupu. Dari analisis data, secara klasikal pada siklus I dan siklus II skor rata-rata aktivitas belajar renang II mahasiswa tergolong aktif dengan perolehan skor 12,91 pada rentang 12,25 $\leq \overline{\boldsymbol{A}}<15,75$ kategori aktif.Sedangkan ketuntasan hasil belajar secara klasikal adalah $100 \%$ Berdasarkandatasiklus I dan siklus II, disimpulkan bahwa penerapan model pembelajaran kooperatif tipe jigsaw dapat meningkatkan aktivitas dan hasil belajar mata kuliah teori dan praktek renang II. Disarankan kepada dosen penjasorkes, agar menerapkan model pembelajaran kooperatif tipe jigsaw dalam proses pembelajaran, karena terbukti dapat meningkatkan aktivitas dan hasil belajar.
\end{abstract}

Kata kunci: model, pembelajaran, aktivitas, hasil belajar, renang.

\begin{abstract}
This research aim was to increase student's activities and learning outcome at swimming II theory and practice subject. This research is classroom action research which is done in 2 cycles. The subject of this research is the second semester students at The Education of Physical, Healthy and Recreation Department. The data was collected by observation of student's activities and learning outcome at swimming in breast stroke and butterfly stroke. From the data analysis, classically the average score of swimming activities II at the cycle 1 and cycle 2 is in active category that is 12.91 stretched about12.25 $\leq \bar{A}<15.75$. And its classical completeness is $100 \%$. Based on the cycle 1 and cycle 2 it can be conclude that the implementation of cooperative learning model type jigsaw is increasing student's activities and learning outcome at swimming II theory and practice subject. It's also suggested to the lecture in the education of physical, healthy and recreation department to implementing this learning model because it's proven to be increasing student's activities and learning outcome.
\end{abstract}

Keywords: Model, Learning, Activities, Learning Outcome, Swim

\section{PENDAHULUAN}

Kemajuan suatu hanya bangsa hanya dapat dicapai melalui pendidikan yang baik. Upaya peningkatan mutu pendidikan itu diharapkan dapat menaikkan harkat dan martabat manusia Indonesia. Untuk mencapai itu, pendidikan harus adaptif terhadap perubahan zaman. Memasuki abad ke-
21 SDM kita sangat tidak kompetitif. Menurut catatan Human Development Resport tahun 2003 versi UNDP, peringkat HDI (Human Development Index) atau kualitas Sumber Daya Indonesia berada di urutan 112 . Indonesia berada jauh di bawah Filipina (85), Thailand (74), Malaysia (58), Brunei Darussalam (31), Korea Selatan 
(30), dan Singapura (28). Jadi keadaan pendidikan kita memang memprihatinkan. Untuk itu, pembaharuan pendidikan harus terus dilakukan (Waluyo,2006:1).

Teori dan praktek renang II sangat penting untuk dikuasai mahasiswa, maka seorang dosen harus berusaha menciptakan suasana atau kondisi belajar yang kondusif sehingga pembelajaran mencapai tujuan secara efektif dan efisien. Dosen hendaknya tidak lagi mengajar sekadar sebagai kegiatan menyampaikan pengetahuan, keterampilan, dan sikap kepada mahasiswa. Dosen hendaknya mengajar untuk membelajarkan mahasiswa dalam konteks belajar bagaimana belajar mencari, menemukan, dan meresapkan pengetahuan, keterampilan dan sikap (Putrayasa, 2005: 2). Dengan mengoptimalkan aktivitas gerak, kreativitas, dan peran mahasiswa diharapkan akan mampu mengembangkan potensi dan kapasitas belajar yang dimilikinya, serta potensi sumber belajar yang terdapat di sekitarnya.

Berdasarkan hasil observasi awal terhadap pembelajaran pada semester sebelumnya dapat disimpulkan bahwa penyampaian materi renang II belum menggunakan model pembelajaran yang tepat. $\mathrm{Hal}$ ini terlihat dari pembelajaran masih didominasi oleh dosen dalam artian mahasiswa hanya menerima materi pelajaran tanpa berusaha mengembangkan kemampuan dan pengetahuan yang dimiliki, kurang perhatian dosen terhadap interaksi mahasiswa dalam kelompok belajar sehingga mahasiswa lebih banyak belajar sendiri. kurangnya perhatian dosen terhadap sistem pembelajaran kelompok sehingga mahasiswa terlalu banyak belajar secara individu, Keterbatasan waktu sehingga proses belajar mengajar tidak dapat dilakukan secara utuh, hal tersebut tentunya berpengaruh terhadap ketuntasan hasil belajar secara klasikal. Observasi hasil belajar renang gaya dada adalah $61,8 \%$ mahasiswa yang tuntas dan $38,2 \%$ mahasiswa yang tidak tuntas, sedangkan ketuntasan observasi hasil belajar renang gaya kupu-kupu adalah $50,9 \%$ mahasiswa tuntas dan $49,1 \%$ mahasiswa tidak tuntas, sehingga tujuan pembelajaran T.P Renang II tidak akan tercapai dengan optimal.

Dalam proses pembelajaran dosen merupakan salah satu komponen penting. Oleh karena itu seorang dosen harus memiliki pengetahuan di bidang pengajaran termasuk keterampilan memilih model pembelajaran, karena model pembelajaran merupakan pola yang dapat digunakan untuk menentukan proses belajar, mengajar, merancang materi pembelajaran, dan memandu pembelajaran di kelas. Menurut Jarolimek (dalam Putrayasa, 2005: 3), ketepatan dosen dalam memilih model pembelajaran akan berpengaruh terhadap keberhasilan dan hasil belajar mahasiswa.

Salah satu model pembelajaran yang perlu digunakan oleh dosen pendidikan jasmani dalam proses pembelajaran adalah model pembelajaran kooperatif tipe Jigsaw Pembelajaran kooperatif tipe Jigsaw bertujuan untuk memberikan keleluasaan kepada mahasiswa untuk menguasai bahan ajar yang diberikan melalui tanya jawab atau diskusi antar sesama anggota kelompok.

Jigsaw adalah tipe pembelajaran kooperatif yang dikembangkan oleh Elliot Aronson's. Model pembelajaran ini didesain untuk meningkatkan rasa tanggung jawab siswa terhadap pembelajarannya sendiri dan juga pembelajaran orang lain. Siswa tidak hanya mempelajari materi yang diberikan, tetapi mereka juga harus siap memberikan dan mengajarkan materi tersebut kepada kelompoknya. Padamodel pembelajaran Jigsaw ini keaktifan siswa (student centered) sangan dibutuhkan, dengan dibentuknya kelompok-kelompok kecil yang beranggotakan 3-5 orang yang terdiri dari kelompok asal dan kelompok ahli

Model pembelajaran koopertif metode jigsaw Isiswa diberikan 
kesempatan untuk berkolaborasi dengan teman sebaya dalam bentuk diskusi kelompok dalam memecahkan suatu permasalahan. Masing-masing kelompok beranggotakan 5-6 orang siswa yang memiliki kemampuan akademik heterogen sehingga dalam 4 suatu kelompok akan terdapat siswa yang berkemampuan tinggi, siswa berkemampuan sedang dan siswa berkemampuan kurang (Nurhadi dkk, 2004: 65).

Menrut Lie ( 1993: 73), bahwa pembelajaran kooperatif model jigsaw ini merupakan model belajar kooperatif dengan cara siswa belajar dalam kelompok kecil yang terdiri atas empat sampai dengan enam orang secara heterogen dan siswa bekerja sama saling ketergantungan positif dan bertanggung jawab secara mandiri. Dalam model pembelajaran jigsaw ini siswa memiliki banyak kesempatan untuk mengemukakan pendapat, dan mengelolahimformasi yang didapat dan dapat meningkatkan keterampilan berkomunikasi, anggota kelompok bertanggung jawab atas keberhasilan kelompoknya dan ketuntasan bagian materi yang dipelajari, dan dapat menyampaikan kepada kelompoknya. (Rusman, 2008.203).

Menurut (Slavin, 1994 : 121)

Tujuan pembelajaran kooperatif tipe jigsaw adalah menciptakan situasi dimana keberhasilan individu ditentukan oleh keberhasilan kelompoknya. Sistem ini berbeda dengan kelompok konvensional yang menerapkan sistem kompetisi, dimana keberhasilan individu diorientasikan pada kegagalan orang lain. Dan tujuan model pembelajaran kooperatif tipe jigsaw itu sendiri adalah memberikan rasa tanggung jawab individu dan kelompok untuk keberhasilan bersama dan untuk saling berinteraksi dengan kelompok lain.

Dengan suasana kelompok yang heterogen mereka dapat saling memotivasi dan membantu antara mahasiswa yang berkemampuan lebih dengan mahasiswa yang berkemampuan kurang dalam pengusaan materi. Sebagai implikasi dari konsep ini, maka mahasiswa hendaknya tidak dipandang sebagai penerima pasif dari suatu program intruksional, tetapi dilihat sebagai bagian yang aktif dan bertanggung jawab atas pembelajaran dirinya (Putrayasa, 2005:3-4). Bertitik tolak dari permasalahan di atas maka penelitian ini berjudul "Penerapan model pembelajaran kooperatif tipe jigsaw untuk meningkatkan aktivitas dan hasil belajar mata kuliah teori dan praktek renang II".

Model pembelajaran jigsaw juga berpengaruh terhadap hasil belajar yang di peroleh oleh siswa. Adapun pengertian hasil belajar antara lain: Hasil belajar merupakan bagian terpenting dalam pembelajaran. Nana Sudjana (2009: 3) mendefinisikan hasil belajar siswa pada hakikatnya adalah perubahan tingkah laku sebagai hasil belajar dalam pengertian yang lebih luas mencakup bidang kognitif, afektif, dan psikomotorik. Dimyati dan Mudjiono (2006: 3-4) juga menyebutkan hasil belajar merupakan hasil dari suatu interaksi tindak belajar dan tindak mengajar.

Sugihartono, dkk. (2007: 76-77), menyebutkan faktor-faktor yang mempengaruhi hasil belajar, sebagai berikut: a. Faktor internal adalah faktor yang ada dalam diri individu yang sedang belajar. Faktor internal meliputi: faktor jasmaniah dan faktor psikologis. b. Faktor eksternal adalah faktor yang ada di luar individu. Faktor eksternal meliputi: faktor keluarga, faktor sekolah, dan faktor masyarakat. Beberapa ahli dalam dunia pendidikan memberikan definisi belajar sebagai berikut. Sntrock dan Yussen (Sugihartono, 2007: 74) mengemukakan bahwa belajar merupakan sebagai perubahan yang relatif permanen karena adanya pengalaman.

Sugihartono (2007: 74) mengemukakan bahwa belajar adalah suatu proses perubahan tingkah laku sebagai hasil interaksi individu dengan lingkungannya dalam memenuhi kebutuhan hidupnya. Slameto (2003: 2) mengemukakan belajar merupakan suatu proses perubahan tingkah laku 
sebagai hasil dari interaksi dengan lingkungannya dalam memenuhi kebutuhan hidupnya. Morgan (Ngalim Purwanto, 2002: 84) mengemukakan belajar adalah setiap perubahan yang relatif menetap dalam tingkah laku yang terjadi sebagai suatu hasil dari latihan atau pengalaman.

Skinner (Dimyati dan Mudjiono, 2006: 9) mengemukakan belajar adalah suatu perilaku. Pada saat orang belajar, maka responnya menjadi lebih baik, sebaliknya, bila ia tidak belajar maka responnya menurun. Gagne (Dimyati dan Mudjiono, 2006: 10) mengemukakan belajar merupakan kegiatan yang kompleks. Hasil belajar berupa kapabilitas. Setelah belajar orang memiliki keterampilan, pengetahuan, sikap dan nilai.

Permasalahan yang akan dikaji dalam penelitian ini adalah (1). Bagaimanakah efektivitas Penerapan model pembelajaran kooperatif tipe jigsaw untuk meningkatkan aktivitas belajar mata kuliah teori dan praktik renang II pada mahasiswa semester II? (2). Bagaimanakah efektivitas Penerapan model pembelajaran kooperatif tipe jigsaw untuk meningkatkan hasil belajar mata kuliah teori dan praktik renang II pada mahasiswa semester II?

Penelitian tindakan ini bertujuan (1). untuk meningkatkan aktivitas belajar mata kuliah teori dan praktek renang II pada mahasiswa semester II., (2). untuk meningkatkan hasil belajar

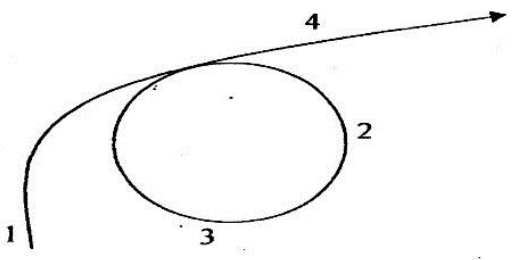

mata kuliah teori dan praktek renang II pada mahasiswa semester II.

Adapun manfaat penelitian ini adalah (1). Untuk menambah wawasan dan pengetahuan tentang model pembelajaran sehingga dapat meningkatkan profesionalisme dosen dalam memilih dan menerapkan model pembelajaran dalam upaya pencapaian tujuan pendidikan, (2). Untuk dapat meningkatkan antusiasme terhadap pelajaran, interaksi mahasiswa dengan mahasiswa dan dosen, kerjasama, aktivitas dalam kelompok belajar, usaha dalam mengikuti pembelajaran, dan partisipasi dalam menyimpulkan materi khususnya dalam mata kuliah teori dan praktek renang II, (3). Untuk dapat meningkatkan aktivitas dan hasil belajar masing-masing individu dan prestasi mahasiswa dalam proses pembelajaran mata kuliah teori dan praktek renang II, (4).Untuk membantu menumbuh kembangkan rasa tanggung jawab dan kerja sama mahasiswa untuk saling menghargai, berbagi pendapat dan pengalaman belajar mata kuliah teori dan praktek renang II, (5). Hasil penelitian ini dapat digunakan bagi pengembangan model pembelajaran dalam pembelajaran renang.

\section{METODE}

Jenis penelitian yang digunakan adalah penelitian tindakan kelas (classroom action research. Adapun rancangan dari penelitian tindakan kelas ini adalah sebagai berikut.
Keterangan:
1. Perencanaan
2. Pelaksanaan
3. Evaluasi
4. Refleksi

\section{Gambar 01 Rancangan Penelitian Tindakan Kelas}

(Suyanto, dkk., 1997: 21)

Sebagai subyek dalam penelitian ini ditetapkan mahasiswa semester II A Jurusan Pendidikan Jasmani, kesehatan dan Rekreasi, FOK Undikhsa Singaraja tahun akademik 2009/2010 yang berjumlah 55 orang yang terdiri dari 6 
mahasiswa putri dan 49 mahasiswa putra. Penelitian ini dilaksanakan selama 2 bulan yaitu dari bulan Agustus sampai Nopember, yang bertempat di kolam Mumbul Singaraja.

Data aktivitas belajar mahasiswa diamati dengan indikator (1). Antusianme mahasiswa dalam mengikuti pembelajaran, (2). Interaksi mahasiwa dengan dosen, (3). Interaksi mahasiswa dengan mahasiswa, (4). Kerjasama kelompok, (5). Aktivitas mahasiswa dalam diskusi kelompok, (6). Usaha mahasiswa dalam mengikuti pembelajaran, (7). Partisipasi mahasiswa dalam menyimpulkan materi pelajaran. Masing-masing indikator memuat 3 deskriptor sehingga skor maksimal ideal aktivitas belajar adalah 21.

Data aktivitas belajar mahasiswa secara klasikal dianalisis berdasarkan skor rata-rata aktivitas belajar mahasiswa $(\bar{A})$, mean ideal (MI) dan standar deviasi ideal (SDI) pada masing - masing siklus sebagai berikut:

$$
\begin{aligned}
& \bar{A}=\frac{\sum_{i=1}^{n} A_{i}}{N} \\
& \mathrm{MI}=\frac{1}{2} \begin{array}{l}
\text { (skor tertinggi ideal }+ \text { skor } \\
\text { terendah ideal })
\end{array} \\
& \text { SDI }=\frac{1}{6} \begin{array}{l}
\text { (skor tertinggi ideal }- \text { skor } \\
\text { terendah ideal })
\end{array}
\end{aligned}
$$

Keterangan :

$$
\begin{aligned}
& \bar{A}=\text { Skor rata-rata aktivitas } \\
& \text { belajar } \\
& A_{i}=\text { Skor aktivitas belajar } \\
& \text { mahasiswa ke-i. } \\
& N=\text { Banyaknya mahasiswa }
\end{aligned}
$$

Skor rata-rata aktivitas mahasiswa yang diperoleh dari perhitungan dikategorikan sesuai dengan penggolongan di atas dengan kriteria keberhasilan dari penelitian ini adalah minimal aktivitas belajar mahasiswa tergolong cukup aktif.

Data hasil belajar diperoleh dari asesmen hasil belajar renang gaya dada dan asesmen hasil belajar renang gaya kupu-kupu. Aspek yang dinilai pada hasil belajar renang gaya dada dan renang gaya kupu-kupu adalah terdiri dari (1). Posisi badan, (2). Gerakan Kaki, (3). Gerakan Lengan, (4). Pernapasan, (4). Koordinasi.

Dalam penelitian ini, peneliti menggunakan analisis statistik deskriptif. Adapun langkah-langkahnya adalah sebagai berikut.

1. Rumus menghitung nilai Tugas, Ujian Tengah Semeter, dan Ujian Akhir Semester, adalah sebagai berikut.

$$
N=\frac{S H T}{S M I} \times \mathrm{NI}
$$

Keterangan :

$$
\begin{array}{ll}
\text { N } & \text { : Nilai } \\
\text { SHT } & : \text { Skor Hasil test } \\
\text { SMI } & : \text { Skor Maksimal Ideal } \\
\text { NI } & : \text { Nilai Ideal dalam skala } \\
& (100)
\end{array}
$$

2. Rumus untuk menghitung nilai akhir yang akan digunakan sebagai rekomendasi penelitian ini adalah sebagai berikut.

$$
N A=\frac{\{(T x 1)+(U T S \times 2)+(U A S x 4)\}}{7}
$$

Keterangan:

$$
\begin{aligned}
& \text { NA } \text { Nilai Akhir } \\
& T: \text { Tugas (membuat makalah } \\
& \text { sistem organisasi } \\
& \text { perlombaan renang) } \\
& \text { UTS : Ujian Tengah Semester } \\
& \text { UAS : Ujian Akhir Semester } \\
& \text { Keberhasilan dalam menempuh }
\end{aligned}
$$
mata kuliah teori dan praktek renang II bagi mahasiswa secara individu minimal mencapai tingkat penguasaan materi 55 \%- 69 \% (Minimal Nilai 2 /C).

\section{HASIL DAN PEMBAHASAN}

Penelitian tidakan kelas ini dilaksanakan di Jurusan Penjaskesrek Universitas Pendidikan Ganesha. Subjek penelitian adalah mahasiswa kelas IIA tahun pelajaran 2009/2010 yang berjumlah 55 orang yang terdiri dari 6 orang mahasiswa putri dan 49 orang mahasiswa putra. Pada siklus I akan berikan pembelajaran renang gaya dada dengan memperhatikan langkahlangkah pembelajaran dalam model 
pembelajaran kooperatif tipe jigsaw. Pada siklus II akan berikan pembelajaran renang gaya kupu-kupu dengan memperhatikan langkahlangkah pembelajaran dalam model pembelajaran kooperatif tipe jigsaw. Pada siklus I dan Siklus II akan diamati aktivitas dan hasil belajar siswa.
Aktivitas belajar Mahasiswa selama pemberian tindakan pada siklus I diamati dalam 3 (tiga) kali pertemuan. Kategori penggolongan aktivitas belajar mahasiswa pertemuan pertama, kedua dan ketiga pada siklus I dapat dilihat pada tabel 1, tabel 2 dan tabel 3 berikut.

Tabel 1 Aktivitas Belajar Renang Gaya Dada Pertemuan Pertama Siklus I

\begin{tabular}{ccccc}
\hline No & Kreteria & $\begin{array}{c}\text { Jumlah } \\
\text { mahasiswa }\end{array}$ & Persentase (\%) & Keterangan \\
\hline 1 & $15,75 \leq \bar{A}$ & 0 & $0 \%$ & Sangat Aktif \\
2 & $12,25 \leq \bar{A}<15,75$ & 4 & $7,3 \%$ & Aktif \\
3 & $8,75 \leq \bar{A}<12,25$ & 50 & $90,9 \%$ & Cukup Aktif \\
4 & $5,25 \leq \bar{A}<8,75$ & 0 & $0 \%$ & Kurang Aktif \\
5 & $\bar{A}<5,25$ & 1 & $1,8 \%$ & Sangat Kurang Aktif \\
\hline \multicolumn{7}{c}{ Jumlah } & 55 & $100 \%$ & \\
\hline
\end{tabular}

Tabel 2 Aktivitas Belajar Renang Gaya Dada Pertemuan Kedua Siklus I

\begin{tabular}{ccccc}
\hline No & Kreteria & $\begin{array}{c}\text { Jumlah } \\
\text { mahasiswa }\end{array}$ & Persentase (\%) & Keterangan \\
\hline 1 & $15,75 \leq \bar{A}$ & 4 & $7,3 \%$ & Sangat Aktif \\
2 & $12,25 \leq \bar{A}<15,75$ & 22 & $40 \%$ & Aktif \\
3 & $8,75 \leq \bar{A}<12,25$ & 29 & $52,7 \%$ & Cukup Aktif \\
4 & $5,25 \leq \bar{A}<8,75$ & 0 & $0 \%$ & Kurang Aktif \\
5 & $\bar{A}<5,25$ & 0 & $0 \%$ & Sangat Kurang Aktif \\
\hline \multicolumn{7}{c}{ Jumlah } & 55 & $100 \%$ & \\
\hline
\end{tabular}

Tabel 3 Aktivitas Belajar Renang Gaya Dada Pertemuan Ketiga Siklus I

\begin{tabular}{ccccc}
\hline No & Kreteria & $\begin{array}{c}\text { Jumlah } \\
\text { mahasiswa }\end{array}$ & Persentase (\%) & Keterangan \\
\hline 1 & $15,75 \leq \bar{A}$ & 26 & $47,3 \%$ & Sangat Aktif \\
2 & $12,25 \leq \bar{A}<15,75$ & 29 & $52,7 \%$ & Aktif \\
3 & $8,75 \leq \bar{A}<12,25$ & 0 & $0 \%$ & Cukup Aktif \\
4 & $5,25 \leq \bar{A}<8,75$ & 0 & $0 \%$ & Kurang Aktif \\
5 & $\bar{A}<5,25$ & 0 & $0 \%$ & Sangat Kurang Aktif \\
\hline \multicolumn{7}{c}{ Jumlah } & 55 & $100 \%$ & \\
\hline
\end{tabular}

Berdasarkan analisis data dan
pembahasan aktivitas belajar mahasiswa pada pertemuan pertama siklus I materi renang gaya dada, terdapat 4 orang mahasiswa tergolong aktif, 50 orang mahasiswa tergolong cukup aktif, dan 1 orang mahasiswa tergolong sangat kurang aktif. Pada pertemuan kedua terdapat 4 mahasiswa yang sangat aktif, 22 orang mahasiswa tergolong aktif, 29 orang mahasiswa tergolong cukup aktif, Sedangkan pada pertemuan ketiga terdapat 26 mahasiswa yang tergolong sangat aktif, 29 orang mahasiswa tergolong aktif. Secara klasikal pada siklus I skor rata-rata aktivitas belajar renang gaya dada mahasiswa tergolong aktif dengan perolehan skor 
13,04 pada rentang $12,25 \leq \bar{A}<$ 15,75 .

Aktivitas belajar mahasiswa selama pemberian tindakan pada siklus II diamati dalam 3 (tiga) kali pertemuan.
Kategori penggolongan aktivitas belajar renang gaya kupu-kupu pertemuan pertama, kedua dan ketiga pada siklus II dapat dilihat pada tabel 4, tabel 5 dan tabel 6 berikut.

Tabel 4 Aktivitas Belajar Renang Gaya Kupu-kupu Pertemuan pertama Siklus II

\begin{tabular}{ccccc}
\hline No & Kreteria & $\begin{array}{c}\text { Jumlah } \\
\text { mahasiswa }\end{array}$ & Persentase (\%) & Keterangan \\
\hline 1 & $15,75 \leq \bar{A}$ & 0 & $0 \%$ & Sangat Aktif \\
2 & $12,25 \leq \bar{A}<15,75$ & 0 & $0 \%$ & Aktif \\
3 & $8,75 \leq \bar{A}<12,25$ & 55 & $100 \%$ & Cukup Aktif \\
4 & $5,25 \leq \bar{A}<8,75$ & 0 & $0 \%$ & Kurang Aktif \\
5 & $\bar{A}<5,25$ & 0 & $0 \%$ & Sangat Kurang Aktif \\
\hline \multicolumn{7}{c}{ Jumlah } & 55 & $100 \%$ & \\
\hline
\end{tabular}

Tabel 5 Aktivitas Belajar Renang Gaya Kupu-kupu Pertemuan kedua Siklus II

\begin{tabular}{ccccc}
\hline No & Kreteria & $\begin{array}{c}\text { Jumlah } \\
\text { mahasiswa }\end{array}$ & Persentase (\%) & Keterangan \\
\hline 1 & $15,75 \leq \bar{A}$ & 0 & $0 \%$ & Sangat Aktif \\
2 & $12,25 \leq \bar{A}<15,75$ & 29 & $52,7 \%$ & Aktif \\
3 & $8,75 \leq \bar{A}<12,25$ & 25 & $45,5 \%$ & Cukup Aktif \\
4 & $5,25 \leq \bar{A}<8,75$ & 0 & $0 \%$ & Kurang Aktif \\
5 & $\bar{A}<5,25$ & 1 & $1,8 \%$ & Sangat Kurang Aktif \\
\hline \multicolumn{7}{c}{ Jumlah } & & $100 \%$ & \\
\hline
\end{tabular}

Tabel 6 Aktivitas Belajar Renang Gaya Kupu-kupuPertemuan ketiga Siklus II

\begin{tabular}{ccccc}
\hline No & Kreteria & $\begin{array}{c}\text { Jumlah } \\
\text { mahasiswa }\end{array}$ & Persentase (\%) & Keterangan \\
\hline 1 & $15,75 \leq \bar{A}$ & 15 & $27,3 \%$ & Sangat Aktif \\
2 & $12,25 \leq \bar{A}<15,75$ & 36 & $65,5 \%$ & Aktif \\
3 & $8,75 \leq \bar{A}<12,25$ & 4 & $7,2 \%$ & Cukup Aktif \\
4 & $5,25 \leq \bar{A}<8,75$ & 0 & $0 \%$ & Kurang Aktif \\
5 & $\bar{A}<5,25$ & 0 & $0 \%$ & Sangat Kurang Aktif \\
\hline \multicolumn{7}{c}{ Jumlah } & & $100 \%$ & \\
\hline
\end{tabular}

Berdasarkan analisis data dan pembahasan pada pertemuan pertama pada siklus IImateri renang gaya kupukuputerdapat 55 (100\%) mahasiswa yang tergolong cukup aktif,. Pada pertemuan kedua terdapat $29(52,7)$ orang mahasiswa tergolong aktif, 25 $(45,5 \%)$ mahasiswa yang tergolong cukup aktif, dan 1 (1,8\%) mahasiswa tergolong sangat kurang aktif. Sedangkan pada pertemuan ketiga terdapat $15(27,3 \%)$ mahasiswa yang tergolong sangat aktif, $36(65,5 \%)$ orang mahasiswa tergolong aktif, 4 (7,2\%) mahasiswa yang tergolong cukup aktif. Secara klasikal pada siklus II skor ratarata aktivitas belajar renang gaya kupu-kupu mahasiswa sebesar 12,78 berdasarkan rentang penggolongan aktivitas belajar mencapai $12,25 \leq \bar{A}<$ 15,75 dalam kategori aktif.

Memperhatikan data aktivitas belajar mahasiswa pada siklus I dan Siklus II, rata-rata aktivitas belajar renang II tergolong aktif dengan perolehan skor 12,91 pada rentang $12,25 \leq \bar{A}<15,75$. 
Berdasarkan analisis data dan pembahasan rata-rata ketuntasan hasil belajar materi renang gaya dada pada siklus I antara lain:8 (14,5\%) orang mahasiswa dengan kategori sangat baik, $32(58,2 \%)$ orang mahasiswa dengan kategori baik, dan 15 (27,3\%) orang mahasiswa dengan kategori cukup. Tingkat penguasaan materi secara klasikal pada materi renang gaya dada mencapai $100 \%$ berdasarkan rentang ketuntasan $85 \%-100 \%$ dalam kategori sangat baik. Analisis data dan pembahasan rata-rata ketuntasan hasil belajar materi renang gaya kupu-kupu pada siklus II antara lain:4 (7,3\%) orang mahasiswa dengan kategori sangat baik, $36(65,5 \%)$ orang mahasiswa dengan kategori baik, 15 (27,2\%) orang mahasiswa dengan kategori cukup. Tingkat penguasaan materi secara klasikal pada materi renang gaya kupukupu mencapai $100 \%$ berdasarkan rentang ketuntasan $85-100 \%$ dalam kategori sangat baik.

Dengan memperhatikan hasil belajar mahasiswa pada siklus I dan siklus I, peneliti merekomendasikan kepada dosen pengampu matakuliah renang dan guru pendidikan jasmani supaya lebih memperhatikan mahasiswa dan siswa yang gerakannya masih salah baik dari posisi badan, gerakan kaki, gerakan lengan, pernafasan dan koordinasi.

Berdasarkan atas data hasil belajar pada siklus I dan siklus II serta nilai tugas yang diberikan maka yang dihitung menggunakan rumus $N A=\frac{\{(T x 1)+(U T S x 2)+(U A S x 4)\}}{7}$

maka didapatkan data ketuntasan hasil belajar sebagai berikut.

Tabel 7 Persentase Kategori Ketuntasan Hasil Belajar Teknik Renang Gaya kupukupu mahasiswa semester II A Jurusan Pendidikan Jasmani, kesehatan dan Rekreasi, FOK Undikhsa Singaraja.

\begin{tabular}{cccccc}
\hline No & Kreteria & $\begin{array}{c}\text { Jumlah } \\
\text { mahasiswa }\end{array}$ & Persentase (\%) & Keterangan & Hasil \\
\hline 1 & $85 \%-100 \%$ & 5 & $9,1 \%$ & Sangat Baik & Tuntas \\
\hline 2 & $70 \%-84 \%$ & 40 & $72,72 \%$ & Baik & Tuntas \\
3 & $55 \%-69 \%$ & 10 & $18,18 \%$ & Cukup & Tuntas \\
4 & $40 \%-54 \%$ & 0 & $0 \%$ & Kurang & Tidak Tuntas \\
5 & $0 \%-39 \%$ & 0 & $0 \%$ & Sangat Kurang & Tidak Tuntas \\
\hline \multicolumn{7}{c}{ Jumlah } & 55 & $100 \%$ & & \\
\hline
\end{tabular}

Ketuntasan aktivitas belajar secara klasikal berada pada kriteria aktif sedangkan hasil belajar secara klasikal mencapai $100 \%$ dengan rincian 5 orang $(9,1 \%)$ berada pada kriteria sangat baik, 40 orang $(72,72 \%)$ berada pada kriteria baik dan 10 orang $(18,18 \%)$ berada pada kriteria cukup. Hal tersebut disebabkan penerapan model pembelajaran kooperatif tipe jigsaw dalam pembelajaran mata kuliah renang II. Penerapan model pembelajaran kooperatif memberikan keleluasaan kepada mahasiswa untuk menguasai bahan ajar yang diberikan melalui tanya jawab atau diskusi antar sesama anggota kelompok. Suasana kelompok yang heterogen memberikan peluang antar mahasiswa dalam kelompok saling memotivasi dan membantu antara mahasiswa yang berkemampuan lebih dengan mahasiswa yang berkemampuan kurang dalam pengusaan materi.

Jadi, dapat disimpulkan bahwa "Penerapan model pembelajaran kooperatif tipe jigsaw dapat meningkatkan aktivitas dan hasil belajar mata kuliah teori dan praktik renang II"

\section{SIMPULAN DAN SARAN}

Berdasarkan analisis data dan pembahasan, dapat ditarik kesimpulan 1). Penerapan model pembelajaran kooperatif tipe Jigsaw dapat meningkatkan aktivitas belajar mata kuliah teori dan praktik renang II., 2). Penerapan model pembelajaran 
kooperatif tipe Jigsaw dapat meningkatkan hasil belajar mata kuliah teori dan praktik renang II.Berdasarkan simpulan, maka dapat diajukan saransaran sebagai berikut. 1). Disarankan kepada dosen pengampu mata kuliah renang dan guru pendidikan jasmani, agar dapat menerapkan model pembelajaran kooperatif tipe Jigsaw, karena model pembelajaran kooperatif tipe jigsaw dapat meningkatkan aktivitas dan hasil belajar. 2). Bagi kampus dan sekolah dapat dijadikan sebagai pedoman dalam pembelajaran renang dan pendidikan jasmani, khususnya pada materi renang gaya dada dan gaya kupu-kupu guna meningkatkan aktivitas dan hasil belajar., 3)Bagi calon peneliti yang berminat untuk meneliti lebih lanjut dengan menggunakan model pembelajaran kooperatif tipe jigsaw, hendaknya mempertimbangkan faktorfaktor lain yang mungkin mempengaruhi penelitian.

\section{DAFTAR PUSTAKA}

Dimyati dan Mudjiono. (2006). Belajar dan Pembelajaran. Jakarta: PT Rineka Cipta.

Lie, Anita \& Prasasti, Sarah.(2004).101 Cara Membina Kemandirian dan Tanggung JawabAnak. Jakarta: Elex Media Komputindo.

Nurhadi, dkk. (2004). Pembelajaran Kontekstual(contextual teaching and learning/ CTL) dan Penerapannya Dalam KBK. Malang: UM press.

Putrayasa, Ida Bagus. 2005. Pembelajaran Bahasa Indonesia Berbasis Inkuiri dalam Upaya Meningkatkan Aktivitas, Kreativitas, dan Logikalitas. Orasi Pengenalan Jabatan Guru Besar Tetap dalam Bidang Bahasa pada Fakultas Pendidikan Bahasa dan Seni IKIP Negeri Sinagaraja, Disampaikan pada sidang terbuka Senat IKIP Negeri Singaraja, Rabu, 23 Maret 2005.
Rosdakarya, 2009. Sugihartono, dkk (2007) Psikologi Pendidikan, Yogyakarta : UNY Press

Rusman. 2008. Pembelajaran Jigsaw. Jakarta: Bumi Aksar

Slameto. 2003. Belajar dan Faktor-faktor yang Mempengaruhinya. Jakarta: Rineka Cipta.Purwanto Ngalim, 2002, Administrasi Dan Supervisi Pendidikan, Bandung: PT. Remaja Rosdakarya.

Slavin, R. E. (1994). Educational Psychology Theory Into Practices. 4th ed. Boston:

Sudjana, Nana, Penilain Hasil Proses Belajar Mengajar, Bandung: Remaj

Suyanto, dkk. 1997. Pedoman Pelaksanaan Penelitian Tindakan Kelas (PTK), Pengenalan Penelitian Tindakan Kelas. Yogyakarta:IKIP Yogyakarta.

United Nations Development. 2003. "Human Development Report 2003". Ally and Bacon Publisher

http://www.unic.un.org.pl/hdr/hdr 2003/hdr03_complete.pdf.

Diunduhtanggal 3 Januari 2010.

Waluyo, Joko. 2006. Pendekatan, Metode dan Teknik Pembelajaran Inovatif. Makalah disajikan pada Pelatihan Penelitian Tindakan Kelas Untuk Perbaikan Kualitas Pembelajaran SD-MI dan SMPMTS. Proyek Desentralisasi Pendidikan Dasar Kabupaten Karangasem. Universitas Pendidikan Ganesha. 